\title{
Industri Rumah Tangga Keripik Pisang Koisna di Kecamatan Mangkutana, 2003-2017
}

\author{
Meriam, H Rasyid Ridha, H Patahuddin. \\ Prodi Pendidikan Sejarah Fakultas Ilmu Sosial Universitas Negeri Makassar \\ merryam1997@gmail.com
}

\begin{abstract}
Abstrak
Penelitian ini bertujuan untuk mengetahui latar belakang berdirinya industri rumah tangga, perkembangan industri, dan dampak industri. Batasan awal penelitian ini diambil pada tahun 2003 karena pada tahun ini merupakan awal mulanya usaha industri rumah tangga keripik pisang Koisna di Mangkutana didirikan. Batasan akhirnya adalah tahun 2017 yang merupakan periode yang menjelaskan perkembangan industri rumah tangga keripik pisang Koisna di Mangkutana. Penelitian di lakukan melalui studi lapangan dan kajian pustaka dengan mengunakan metode sejarah melalui beberapa tahapan kerja, yaitu heuristik, kritik, interpretasi, dan historiografi. Hasil penelitian ini menunjukkan bahwa industri rumah tangga keripik pisang Koisna berdiri dan dilatar belakangi oleh adanya seorang karyawan yang telah di PHK sehingga berkeinginan untuk membentuk industri makanan dengan mengolah pisang tersebut. Perkembangan industri makanan keripik ini dalam kurun waktu 2003-2017 telah membawa perubahan dalam hal produksi yang meningkat dari tahun ke tahun dengan mengikuti musim buah. Kehadiran industri rumah tangga keripik pisang Koisna membawa dampak sosial dalam hal perubahan interaksi yang semakin kuat dengan pekerja industri. Selain itu, keberadaan industri rumah tangga di Mangkutana telah membantu kehidupan perekonomian masyarakat dalam hal memberikan lapangan kerja.Kesimpulan bahwa dalam perkembangan industri keripik pisang di Mangkutana selalu mengalami peningkatan setiap tahun. Hal ini karena banyaknya permintaan dari konsumen. Pemasaran keripik pisang Koisna ini telah sampai di luar Mangkutana dan sampai sekarang sudah lebih banyak di pesan dari berbagai konsumen.
\end{abstract}

\section{Kata Kunci : Industri, Keripik, dan Mangkutana}

\begin{abstract}
This study aims to determine the background of the establishment of the home industry, industrial development, and industrial impact. The initial limitation of this study was taken in 2003 because this year was the beginning of the Koisna banana chips home industry in Mangkutana. The final limit is 2017 which is the period that explains the development of the Koisna banana chip home industry in Mangkutana freightana.The research was conducted through field studies and literature studies using historical methods through several stages of work, namely heuristics, criticism, interpretation, and historiography. The results of this study indicate that the home industry of Koisna banana chips stands and is motivated by the existence of an employee who has been laid off so that he wishes to form a food industry by processing the banana. The development of the chip food industry in the period 2003-2017 has brought changes in terms of production which increased from year to year by following the fruit season. The presence of the Koisna banana chips home industry has a social impact in terms of changing interactions that are getting stronger with industrial workers. In addition, the existence of a home industry in Mangkutana freightana has helped the community's economic life in terms of providing employment.The conclusion that in the development of the banana chips
\end{abstract}


industry in Mangkutana freightana is always increasing every year. This is because of the many requests from consumers. The marketing of Koisna banana chips has reached outside Mangkutana conveyana and until now it has been mostly ordered by various consumers.

\section{Keywords: Industry, Chips, and Mangkutan}

\section{A. Pendahuluan}

Peranan Usaha Kecil dan Menengah (UKM) dalam perekonomian Indonesia pada dasarnya sudah besar sejak dulu. Namun demikian sejak krisis ekonomi melanda Indonesia, perananan UKM meningkat dengan tajam. Dalam pembangunan ekonomi di Indonesia, Usaha Kecil Menengah (UKM) selalu digambarkan sebagai sektor yang mempunyai peranan yang penting, karena sebagian besar jumlah penduduknya berpendidikan rendah dan hidup dalam kegiatan usaha kecil baik di sektor tradisional maupun modern. (Partomo, 2002)

Bidang pertanian merupakan sumber bahan baku utama bagi bidang industri rumah tangga. Adanya kerjasama yang baik antara industri dan pertanian, akan menciptakan keseimbangan satu sama lain, karena bidang pertanin yang kuat akan mendukung terciptanya industri dengan baik (Kartasapoetra, 1992). Bidang industri telah menunjukkan peran yang penting bagi perekonomian, baik dalam menambah sumber pendapatan negara maupun dalam memberikan kesejahteraan bagi masyarakat luas. Industri rumah tangga dan industri yang pada umumnya terdapat di pinggiran daerah perkotaan erat kaitannya dengan bidang pertanian (Wie, 1997)

Begitu pula halnya di Kecamatan Mangkutana, kegiatan usaha industri memberi kesempatan kerja kepada masyarakat, karena dalam usaha industri keripik pisang ini tidak menentu pendidikan yang tinggi melainkan kemauan dalam bekerja.

Di Sulawesi Selatan, tepatnya di Kecamatan Mangkutana, terdapat satu industri rumah tangga yang bergerak di bidang pengolahan bahan makanan berupa pisang, yakni industri rumah tangga keripik pisang Koisna yang berdiri sejak tahun 2003. Industri rumah tangga ini didirikan oleh Bambang Hernowo dan memperkerjakan empat tenaga kerja yang masih kerabat dekat dan juga di bantu oleh istri dan ketiga anaknya (Hernowo B. , 2018).

Industri rumah tangga keripik pisang Koisna yang berada di Kecamatan Mangkutana dapat dikatakan sebagai satu industri rumah tangga yang menarik, hal ini dikarenakan produk keripik ini digoreng dengan cara yang masih sederhana, yakni menggunakan tungku tanah yang berukuran besar. Jadi cita rasa tradisionalnya masih terjaga. Selain cita rasa yang terjaga, proses pengelolaan industri dan distribusi dikendalikan oleh kerabat-kerabat terdekat. Lebih lanjut, terdapat tiga alasan utama mengapa industri ini tetap bertahan: pertama, prodak berupa makanan, diketahui bahwa bisnis yang menguntungkan dan cukup populer di kalangan konsumen adalah bisnis makanan. Kedua, pemberdayaan sumber daya manusia, dalam artian tenaga kerja yang digunakan berasal dari kerabat terdekat. Ketiga, biaya yang dikeluarkan pada umumnya kecil. Industri rumah rangga keripik pisang Koisna yang berdiri di tahun 2003 ini, pendiriannya dilatarbelakangi dengan peristiwa pemutusan hubungan kerja (PHK) karyawan PT. Sindoka, di mana salah satu karyawan yang terkena dampak pemutusan hubungan kerja tersebut adalah Bambang Hernowo. Olehnya itu, Bambang Hernowo selaku kepala rumah tangga yang menafkahi seorang istri dan tiga orang anak berusaha mencari jalan keluar agar "asap rumah tetap mengepul”, salah satu jalan ialah mendirikan industri rumah tangga yang memproduksi keripik pisang dengan merek 
Koisna (Hernowo B. , latar Belakang, 2018).

Industri rumah tangga ini masih tetap bertahan dan eksis, bahkan dari hasil industri rumah tangga ini, Bambang Hernowo mampu menyekolahkan istri dan kedua anaknya hingga ke jenjang sarjana. Berangkat dari hal itu, penulis tertarik untuk mengulas mengenai narasi sejarah masyarakat kecil yang bergulat dalam industri rumah tangga yang sudah berdiri sejak tahun 2003 dan merupakan industri rumah tangga pertama yang ada di Kecamatan Mangkutana.

\section{B. Metode Penelitian}

Sejak penelitian dan penulisan sejarah dilakukan secara ilmiah maka penelitian dan penulisan sejarah menggunakan metode sejarah. Metode itu sendiri berarti suatu cara, prosedur, atau teknik untuk mencapai sesuatu tujuan secara efektif dan efisien (Daliman, 2012). Juga dikatakan bahwa metode adalah cara untuk berbuat atau mengerjakan sesuatu dalam suatu sistem yang terencana dan teratur.

Jadi, metode selalu erat hubungannya dengan prosedur, proses, atau teknik yang sistematis untuk melakukan penelitian disiplin tertentu.Hal ini dimaksudkan untuk mendapatkan objek penelitian (Pranoto, 2010).

\section{Heuristik}

Heuristik merupakan tahap awal dari metode penelitiaan sejarah, dimana pada tahap ini seorang peneliti mencari dan mengupayakan penemuan atas sumber sejarah yang memiliki keterkaitan dengan sumber penelitian.

Mengingat sifatnya sistematis, maka tahap-tahap dari metode sejarah tidak dapat ditukar-balik atau mendahulukan kritik, interpretasi, ataupun historiografi. Semua jenis tulisan atau penelitian tentang sejarah menempatkan sumber sejarah sebagai syarat mutlak yang harus ada.Tanpa sumber sejarah, kisah masa lalu tidak dapat direkonstruksi oleh sejarawan (hamid \& Majdid, 2011).

Heuristik merupakan langkah awal dari metode penelitian sejarah, dimana pada tahap ini seorang peneliti mencari dan mengupayakan penemuan atas sumber sejarah yang memiliki keterkaitan dengan objek penelitian.Sumber sejarah tersebut dapat berupa catatan, tradisi lisan, dan setiap titik atau secercah apapun yang memberikan penerangan bagi cerita kehidupan masyarakat.

\section{Kritik}

Setelah sumber terkumpul maka tahap selanjutnya adalah kritik, dimana tahapan ini dilakukan penganalisaan sumber untuk menentukan otensititas dan kredibilitas. Semua sumber sejarah yang ditentukan tersebut sebelumnya mesti mengalami verifikasi. Sebab tidak semua sumber dapat langsung digunakan. Dan dua aspek yang perlu mengalami kritikan terlebih dahulu yakni otentisitas (keaslian sumber) dan kredibilitas (tingkat kebenaran informasi) dari sumber sejarah tersebut.

\section{Interpretasi}

Tahapan selanjutnya setelah proses kritik adalah penginterpretasian. Pada hakikatnya, interpretasi sejarah sering disebut dengan analisis sejarah. Dalam hal ini, ada dua metode yang digunakan, yaitu analisis dan sintesis, keduanya dipandang sebagai metode utama di dalam interpretasi.

Interpretasi merupakan usaha untuk mewujudkan rangkaian data-data yang mempunyai kesesuaian satu sama lain dan bermakna (Widja, 1989). Sumber-sumber yang berupa tulisan telah lolos dari kritik, kemudian dilakukan suatu penafsiran dari bahan-bahan tadi. Pada tahap ini telah dapat ditetapkan dari fakta-fakta yang teruji. Dalam tahap ini subjektivitas peneliti tampak mulai berperan. Imajinasi dibutuhkan pada tahap ini untuk menafsirkan seluruh kejadian berdasakan data-data yang telah terkumpul. 


\section{Historiografi}

Historiografi merupakan tahapan akhir dari seluruh rangkaian prosedur kerja dari metode historis dimana didalamnya menggambarkan cara penulisan, pemaparan atau pelaporan hasil penelitian sejarah yang telah dilakukan.

Berdasarkan penulisan sejarah itu pula akan didapat nilai apakah penelitian ini berlangsung sesuai dengan prosedur yang digunakan atau tidak, apakah sumber atau data yang mendukung penarikan kesimpulan memiliki validasi kredibilitas yang memadai ataukah tidak dan sebagainya. Sehingga penulisan tersebut dapat dikatakan menentukan mutu penelitian sejarah itu sendiri.

\section{Pembahasan}

1. Munculnya industri rumah tangga kerpik pisang Koisna di Kecamatan Mangkutana

\section{a. Latar Belakang Berdirinya}

Latar belakang berdirinya perusahaan yang satu dengan perusahaan yang lainnya pastilah berbeda-beda. Hal tersebut dikarenakan adanya perbedaan di dalam bidang yang ditangani antara sebuah perusahaan yang satu dengan perusahaan yang lain seperti halnya dengan salah satu industri rumah tangga yang bergerak dalam sektor produksi makanan ringan di Kecamatan Mangkutana yang bernama keripik pisang Koisna yang letaknya berada di desa Sindu Agung, Kecamatan Mangkutana, Kabupaten Luwu Timur.

Industri rumah tangga keripik pisang Koisna merupakan perusahaan skala menengah atau lebih khusus kepada industri rumah tangga dan di miliki perseorangan dan bersifat rumah tangga, karena hanya dilakukan di rumah sendiri dan para pekerjanya berasal dari kalangan keluarga atau kerabat mereka sendiri. Perusahaan perseorangan adalah bentuk badan usaha, dimana pemilikan perusahaan sepenuhnya terletak di tangan satu orang. Dengan sendirinya pimpinan perusahaan terletak pada tangan mereka.

Banyaknya desakan dan tuntutan ekonomi yang harus dipenuhi pada zaman ini. Selain itu, kurangnya lowongan kerja dan meledaknya sumber daya manusia, maka sebagian masyarakat harus membuat lapangan kerjanya sendiri atau mendirikan usaha menengah, usaha kecil atau yang dikenal home industri untuk memenuhi kebutuhan ekonominya.

Usaha industri rumah tangga keripik pisang Koisna yang ada di Mangkutana pada awalnya dirintis sejak pemilik usaha tersebut mendapat pemutusan hubungan kerja di PT. Sindoka. PT Sindoka sendiri merupakan perkebunan kelapa Hibrida yang telah berdiri tahun 1986. Pemilik usaha keripik pisang Koisna sendiri pernah bekerja sebagai security sejak tahun 1990 . Tetapi pada tahun 2002 PT Sindoka mengalami kebangkrutan, sehingga perusahaan tersebut melakukan pemutusan hubungan kerja (PHK) kepada semua karyawannya.

Dan kemudian pada tahun 2003 usaha ini baru di mulai. Usaha ini yang berbentuk home industry (industri rumah tangga). Dimana bahan baku dan proses produksinya masih sangat terbatas serta sangat sederhana sekali. Dengan di dasari pengalaman dan mempelajari buku-buku yang ada kaitannya dengan keripik pisang maka industri ini mulai berkembang. Industri rumah tangga keripik pisang ini di mulai dengan modal Rp.300.000 yang merupakan uang pesangon dari tempat bekerja sebelumnya (Hernowo B. , latar Belakang Belakang Berdirinya Industri, 2019).

\section{b. Riwayat Pendiri}

Bambang Hernowo dilahirkan di Bone pada tanggal 9 Oktober 1962, ayahnya bernama Ponijan dan ibunya bernama Musiem Sukerti. Sejak kecil tinggal bersama orangtuanya dan merupakan anak 
pertama dari 10 bersaudara, ayahnya seorang polisi dan ibunya merupakan anggota kemala bayangkari.Bambang Hernowo menempuh pendidikan hingga jenjang SMA. Ia berpindah-pindah sekolah karena mengikut tempat bertugas ayahnya di Enrekang dan Polopo.Pada saat menginjak usia dewasa, Bambang Hernowo menikah dengan Jumiati pada tahun 1988 di Mangkutana, saat itu ia sedang honor di Samsat Palopo, SK sempat keluar namun tidak di izikan oleh keluarga untuk ke Palopo karena akses jalan pada saat itu masih sulit ditempuh dan keluaraga juga melarang dengan alasan tidak baik meninggalkan keluarga dalam jangka waktu yang lama. Oleh karena itu iahanya memilih untuk melihat peluang pekerjaan yang ada di Mangkutana, yaitu sekitar tahun 90-an ia masuk bekerja di Perusahaan PT. Sindoka menjadi seorang security. Ia menjalani profesi tersebut kurang lebih selama 10 tahun kemudian pada tahun 2002 di PHK.

\section{c. Awal Usaha}

Untuk menciptakan industri rumah tangga, seorang pengusaha harus memiliki keinginan yang kuat untuk berhasil, betapa pun banyaknya halangan yang akan ditemui nantinya. Bambang Hernowo memulai usaha industri keripik pisang.

Awal usahanya tidak langsung berjalan mulus, setiap hari beliau mencoba untuk mempromosikan hasil produksinya di mulai dari penjual keripik hasil industri dengan cara berkeliling ke daerah sekitar Kecamatan Mangkutana, menempuh perjalanan dengan jalan kaki saja kebetulan pada saat itu beliua bertemu dengan pemilik minimarket Surya Kencana, minimarket ini terletak di Kecamatan Tomoni yang bertetangga langsung dengan Kecamatan Mangkutana. Pemilik minimarket tersebut menawarkan untuk bekerja sama dengan Bambang Hernowo dengan cara menyuplai hasil produksinya untuk dijual pada minimarketnya. Pada awalnya pak Bambang dan istri hanya memproduksi keripik perharinya hanya sekitar 12 bungkus saja. Namun, setelah dikenal masyarakat jumlah produksi industri koisna milik pak Bambang ini pun mulai bertambah perbulannya.

Hubungan kerja sama antara Bambang Hernowo dengan minimarket Sinar Wajo yang berada di Kecamatan Tomoni berlangsung lama, permintaan konsumen yang semakin meningkat juga mempengaruhi banyaknya produksi akan keripik pisang ini.

Industri Pak Bambang dengan istrinya ini berdiri diatas tanah seluas $\pm 240 \quad \mathbf{M}^{2}$. Lokasi industri tersebut berada di Desa Sindu Agung Kecamatan Mangkutana Kabupaten Luwu Timur, yang teletak tepat di samping rumah Pak Bambang dengan tempat pengolahan dengan luas $3 \times 7 \quad \mathbf{M}^{2}$. Dalam proses pengolahannya masih banyak menggunakan tenaga penggerak manusia. Sistem pemasaran pada awal berdirinya hanya di daerah Kecamatan Mangkutana saja.

2. Perkembangan Industri Rumah Tangga Keripik Pisang Koisna di Kecamatan Mangkutana.

a. Tahun 2003

Tahun 2003 awal usaha ini didirikan oleh Bambang Hernowo beserta istrinya Jumiati, awal usahanya pak Bambang memang masih banyak hambatan yang dilalui namun karena kegigihannya mempromosikannya, saat itu beliau membawa sampel keripik pisangnya sebanyak $2 \mathrm{Kg}$ di kantor ketika ada kegiatan rapat. Respon orang yang mengkonsumsinya positif kemudian mengikuti pelatihan di dinas Kesehatan Kabupaten Luwu Utara yaitu sosialisasi keamanan pangan dari Dinas Kesehatan dan Badan POM dan mendapatkan nomor PIRT.

\section{b. Tahun 2004-2008}

Produksi keripik pisang Koisna ini sudah agak meningkat. Hal ini ditandai dengan jumlah yang di produksi perbulan itu sudah meningkat yaitu sebanyak $15 \mathrm{Kg}$ setiap 1 kali produksi, dan proses produksi yang dilakukan satiap bulannya sebanyak 3 
PATTINGALLOANG

COJurnal Pemikiran Pendidikan dan Penelitian Kesejarahan,

kali. Permintaan akan keripik ini juga semakin bertambah yaitu mulai pasarkan di minimarket, sekolah, dan hotel.Masyarakat

Tabel 3.2 Proses Produksi Industri Keripik Pisang Koisna dari Tahun

juga semakin banyak yang mengetahtilo industri keripik ini kemudian berdatangan langsung untuk membelinya harga per $\mathrm{K}_{\mathrm{g}}$ keripik tersebut yaitu Rp. 15.000,00.

\section{c. Tahun $2009-2014$}

Dalam perkembangan selanjutnya, selama periode 2009-2014 produksi keripik pisang Koisna mencapai puncak kejayaannya yaitu setiap kali produksi bisa menghasilkan 300-350 $\mathrm{Kg}$ dan pencapai 6 kali pengolahan dalam setiap bulannya. Pada masa kejayaan ini pemilik industri keripik pisang mampu menyekolahkan istrinya hingga pada jenjang sarjana pada Jurusan Pertanian, dan juga pemilik industri membeli 2 kendaraan motor. Harga per $\mathrm{Kg}$ keripik pisang tersebut naik menjadi Rp. 15.000,00 hingga Rp. 25.000,00 per Kg. produksi keripik pisang ini sendiri tidak hanya menyebar di daerah sekitar Kecamatan Mangkutana saja, melainkan sudah mulai merambah ke daerah-daerah lain seperti Masamba hingga ke Kota Palopo.

\section{d. Tahun 2015-2017}

Pada tahun ini, produksi keripik pisang ini agak sedikit menurun. Dikarenakan, hasil buah pisang yang tidak sebanyak tahun-tahun sebelumnya. Hasil produksi hanya mencapai 250-300 $\mathrm{Kg}$ setiap kali proses produksinya dan hanya mengolah 45 kali saja setiap bulannya. Memang hasil produksi menurun, tetapi harga keripik pisang ini per Kgnya naik menjadi Rp. 45.000,00.Pada tahun tersebut pemilik industri mampu menyekolahkan anakanaknya hingga ke jenjang sarjana, dan pemasarannya pun semakin luas hingga merambah ke luar provinsi yaitu Papua, Bali dan Kalimantan (Bambang, 2019). 2003-2017

\begin{tabular}{|c|c|c|} 
Tahun & $\begin{array}{c}\text { Jumlah Produksi } \\
\text { Per-Bulan }\end{array}$ & Harga \\
\hline 2003 & 12 Bungkus & Rp.12.000/kg \\
\hline $2004-2008$ & 270 Bungkus & Rp. $15.000 / \mathrm{kg}$ \\
\hline $2009-2014$ & 10.800 Bungkus & Rp.25.000/kg \\
\hline $2015-2017$ & 9.000 Bungkus & Rp. $45.000 / \mathrm{kg}$ \\
\hline
\end{tabular}

Sumber: Diolah dari Hasil Wawancara dengan Bambang Hernowo

3. Dampak Sosial Ekonomi Industri

Rumah Tangga Keripik Pisang Koisna di Kecamatan Mangkutana

a. Dampak Industri Rumah Tangga Terhadap Kehidupan Pengusahanya

1) Dampak Sosial

Sebagaimana sebagian masyarakat mencoba peruntungan mendirikan industri rumahan. Demikian pula dengan yang telah dilakoni oleh Bambang Hernowo dan istrinya, mendirikan usaha industri rumah tangga keripik pisang. Usahanya tersebut telah membawa banyak pengaruh, terutama pengaruh sosial bagi pemilik industri rumah tangga keripik pisang Koisna ini. Salah satu pengaruhnya adalah semakin membaiknya interaksi sosial antar pemilik industri dengan masyarakat sekitar dan juga karyawan

Sumbangan positif lainnya dalam kehidupan sosial adalah pada bidang pendidikan. Sebelum industri rumah tangga keripik pisang tumbuh sebagai mata pencaharian, pemilik industri rumah tangga sangat pasif mendorong keluarganya untuk melanjutkan pendidikan ke jenjang yang lebih tinggi. Bahkan dengan hasil industri rumah tangga keripik ini pemilik mampu menyekolahkan istrinya ke jenjang perguruan tinggi di susul dengan anakanaknya. Peningkatan ini disebabkan oleh perkembangan zaman yang menuntut adanya pengetahuan dan keterampilan (Hernowo B. , Dampak Sosial, 2009).

Dampak sosial yang ini yang sangat terlihat yaitu hubungan bermasyarakat yang berjalan dengan baik karena ketika ada kegiatan-kegiatan yang dilakukan di 
kampung seperti kegiatan keagamaan pemilik industri keripik pisang Koisna memberikan keripiknya untuk dijadikan cemilan. Begitu pula jika menjelang hari raya Idul Fitri pemilik industri menjadikannya parsel untuk tetanggatetangga yang kurang mampu. (Jumiati, 2019)

\section{2) Dampak Ekonomi}

Berdiri dan berkembangnya industri rumah tangga keripik pisang Koisna di Mangkutana telah membawa dampak ekonomi bagi kehidupan pemilik industri dan juga masyarakat sekitar. Dampak yang terlihat adalah bertambahnya lapangan pekerjaan baru bagi masyarakat sekitar dan juga adanya perubahan mata pencaharian pagi pemilik industri. Dampak lainnya adalah semakin bertambahnya pendapatan. ke Bertambahnya pendapatan sangat dirasakan oleh pemilik industri dan juga tenaga kerja industri rumah tangga keripik pisang Koisna di Mangkutana. Meningkatnya pendapatan pemilik industri rumah tangga keripik pisang Koisna sangat dirasakan dengan hal kesejahteraan
keluarga seperti terpenuhnya kebutuhan seharihari

\section{b. Dampak Industri Rumah Tangga Terhadap Kehidupan Karyawan \\ 1) Dampak Sosial}

Dampak sosial yang di rasakan oleh para karyawan yang bekerja pada industri rumah tangga keripik pisang Koisna ini yaitu terjalinnya hubungan yang baik antar pemilik industri dan para pekerja. Hal tersebut terlihat dari nilai gotong royong dan kebersamaan dalam menjalankan tugasnya untuk memenuhi permintaan konsumen yang ada.

Karyawan yang bekerja pada industri rumah tangga keripik pisang Koisna tidak melihat latarbelakang pendidikan seseorang yang diutamakan adalah kemauan untuk bekerja dan disiplin yang tinggi. Namun meskipun mereka memiliki tingkat pendidikan yang rendah tapi dalam kehidupan bermasyarakat mereka tetap mengutamakan pendidikan terutama bagi anak-anak mereka sebagai penerus bangsa. Mereka pula memiliki pandangan terbuka terhadap kehidupan di era modern seperti tingkat pendidikan tinggi dikaitkan dengan pendapatan yang lebih besar, kesejahteraan yang lebih baik, dan jabatan yang lebih tinggi dalam pekerjaaan.

\section{2) Dampak Ekonomi}

Hadirnya industri rumah tangga keripik pisang Koisna memberikan dampak yang sangat baik bagi tetangga sekitarnya, karena dapat membuka lapangan pekerjaan dan berperan dalam mengurangi tingkat pengangguran masyarakat yang ada di Kecamatan Mangkutana.Adanya industri rumah tangga ini sangat berpengaruh pada kesejahteraan keluarga dan masyarakat, peningkatan kesejahteraan tesebut dapat dilihat dalam beberapa hal, seperti persoalan biaya pendidikan anak-anak, kendaraan yang di miliki dan rumah yang mereka miliki (Darmiati, 2019).

Dampak yang sangat terlihat dengan jelas dengan adanya industri rumah tangga keripik pisang Koisna ini yaitu kepemilikan fasilitas hidup seperti kepemilihan atas alat elektronik dan jenis kendaraan seseorang yang berbanding lurus dengan pendapatan, ketika pendapatan melebihi pengeluaran maka kesempatan untuk memiliki fasilitas hidup pun lebih tinggi. Oleh karena keberadaan industri ini sudah berpengaruh terhadap pendapatan, hal ini secara tidak langsung membuat karyawan yang bekerja pada sektor industri tersebut memiliki kemajuan.

Industri rumah tangga ini merupakan salah satu sarana bagi masyarakat yang ada di Kecamatan Mangkutana untuk lebih giat bekerja dan berusaha. Selain itu juga memberi manfaat bagi kesejahteraan.Pendapatan meningkat, hal ini terjadi karena industri ini mampu membuka lapangan pekerjaan dengan beralih dari sektor pertanian ke sektor industri. Mereka yang dulunya tidak memiliki pekerjaan kemudian terserap dalam industri ini, sehingga memberi peluang yang besar dalam memenuhi kebutuhan sehari-hari dan kebutuhan yang lain.

\section{c. Dampak Industri Rumah Tangga Terhadap Kehidupan Petani Pisang}

\section{Dampak Sosial}

Munculnya industri rumah tangga di suatu daerah akan menimbulkan dampak bagi masyarakat sekitar. Seperti halnya yang terjadi di Kecamatan Mangkutana setelah 
berdiri dan berkembangnya industri ruamah tangga keripik pisang ini telah membawa pengaruh terhadap kehidupan petani pisang. Perubahan tersebut adalah adanya perubahan pola pikir dan wawasan pada petani pisang. Perubahan ini terlihat dari kesadaran petani akan pentingnya pendidikan.

Sebelum berdirinya industri keripik pisang Koisna di Mangkutana, petani pisang tidak begitu peduli dengan pendidikan anaknya. Biasanya hanya sekedar tidak buta huruf. Akan tetapi, setelah berdirinya industri keripik pisang ini, petani pisang mulai menyadari akan pentinya pendidikan. Petani bekerja sebagai pemasok bahan baku utama produksi keripik pisang. Meskipun petani pisang tersebut tidak memiliki pendidikan yang tinggi sehingga hal ini membuat petani sadar untuk dapat memiliki pekerjaan yang baik dengan memiliki keahlian yang khusus (Parerung, 2019).

Perubahan sosial lain yang muncul dalam kehidupan petani pisang adalah perubahan struktur sosial yang terlihat dari perubahan status sosial. Dimana setiap masyarakat senantiasa mempunyai penghargaan tertentu terhadap sesuatu.Soekanto mengungkapkan bahwa dalam masyarakat ada sesuatu yang dihargai, maka hal ini dapat menjadi bibit yang yang dapat menumbuhkan sistem dalam masyarakat itu

\section{Dampak Ekonomi}

Industri rumah tangga keripik pisang Koisna di Mangkutana menimbulkan pengaruh dalam kehidupan petani. Terbukanya lapangan pekerjaan menyebabkan meningkatnya pendapatan petani sehingga dapat memajukan taraf hidup masyarakat. Keberadaan industri rumah tangga keripik pisang Koisna telah merubah kondisi perekonomian petani yang bisa dibilang lebih baik dan lebih maju dari sebelum adanya industri keripik pisang ini. Kondisi ini bisa dilihat dari taraf hidup petani yang meningkat.

Aktifitas ekonomi yang dilakukan oleh manusia merupakan usaha untuk mencapai mencapai kemakmuran. Kemakmuran dalam ilmu ekonomi adalah suatu keadaan yang mnunjukkan suatu keseimbangan anatar kebutuhan hidup dengan alat pemuas kebutuhan (Tahir, 1992). Manusia dikatakan makmur jika segala macam kebutuhan hidup dapat dipenuhi secara pantas. Hidup makmur merupakan keinginan setiap manusia. Sementara itu, untuk mencapai kemakmuran, manusia senantiasa harus bekerja keras baik di sektor formal maupun informal.

Salah satu yang menjadi pilihan untuk hidup makmur adalah bekerja sebagai pemasok bahan baku dalam industri rumah tangga keripik pisang Koisna. Pada dasarnya setiap manusia bekerja untuk memenuhi kebutuhan hidupnya. Pemeliharaan kesejahteraan tidak terbatas pada faktor-faktor yang bersifat ekonomis karena kesejahteraan manusia tidak terlepas dari kebutuhan jasmani dan rohaninya. Salah satu indikator untuk mengetahui peningkatan kesejahteraan petani dapat dilihat dari adanya peningkatan sarana perumahan.

Gaya hidup dari mereka juga terlihat dalam kehidupan sehari-hari petani pisang. Hal in terlihat dari cara mengenakan pakaian. Petani sudah bisa membeli pakaian yang bagus dan juga mengikuti zaman yang semakin modern. Di samping itu, bila ada warga yang mengadakan pesta atau syukuran, para petani mulai datang membantu baik moril maupun materil.

\section{Kesimpulan}

Data hasil penelitian, setelah melalui tahap kritik dan interpretasi, dan analisis data, maka hasil penelitian ini disimpulkan sebagai berikut; latar belakang berdirinya industri rumah tangga keripik pisang Koisna di Mangkutana yaitu awalnya karena Bapak Bambang Hernowo atau pemilik industri rumah tangga ini mendapat pemutusan hubungan kerja di PT. Sindoka yang merupakan perkebunan kelapa Hibrida di mana pemilik usaha ini bekerja sebagai security di perkebunan tersebut tepatnya pada tahun 2002. Pada tahun 2003 usaha in imulai di buka berbekal dengan keterampilan memasak dan tekad yang kuat. Istrinya juga merupakan karyawan 
pembuat keripik pada bos PT. Sindoka tersebut. Pada saat itu juga ketersediaan bahan utama dari usaha tersebut yaitu pisang melimpah.

Perkembangan industri rumah tangga keripik pisang Koisna di Kecamatan Mangkutana di mulai pada tahun 2003 yang merupakan tahun pertama diproduksinya keripik ini. Pada awalnya hanya memproduksi sekitar $10 \mathrm{Kg}$ keripik per 3 kali olahan. Jadi pada awal usaha ini pengusaha sudah memproduksi $30 \mathrm{Kg}$ setiap bulannya. Di tahun 2004-2008, produksi keripik pisang ini sudah agak sedikit meningkat. Hal ini ditandai dengan jumlah keripik pisang yang diproduksi juga bertambah menjadi $15 \mathrm{Kg}$ setiap satu kali mengolah, dengan proses produksi sebanyak 3 kali setiap bulannya. Tahun 2009-2014, produksi keripik pisang ini meningkat dengan pesat ditandai dengan di produksinya keripik pisang ini sebanyak 200-350 Kg keripik setiap kali mengolah dan banyaknya pengolahan dalam satu bulan itu mencapai 6 kali pengolahan. Saat ini juga permintaan akan produksi dan wilayah pemasaran semakin meluas. Dan pada tahun 2015-2018 permintaan akan keripik ini agak menurun yaitu 250-300 $\mathrm{Kg}$ dan hanya mengolah sebanyak 4-5 kali saja setiap bulannya, tetapi pada tahun tersebut harga akan keripik perkilogramnya yaitu sekitar Rp. 40.000,00 hinga Rp. 45.000,00. Sehingga dapat dikatakan bahwa pendapatan dari industri tersebut meningkat setiap tahunnya.

Dampak industri rumah tangga keripik pisang Koisna di Kecamatan Mangkutana terhadap kehidupan pengusahanya, karyawan dan petani yaitu dalam bidang sosial adanya perubahan pola piker dan wawasan, adanya perubahan stuktur sosial, semakin membaiknya interaksi sosial antara pemilik industri, petani, dan juga karyawan, semakin meningkatnya kesadaran penduduk akan arti pentingnya pendidikan dan terciptanya kelas menengah baru yaitu golongan wiraswasta. Dampak ekonominya yaitu, peningkatan pendapatan, adanya perubahan gaya hidup yaitu terlihat dari adanya alat komunikasi dan barang-barang mewah lainnya, meningkatnya kesejahteraan keluarga dengan terpenuhinya kebutuhan sehari-hari, serta pergeseran alat transportasi.

\section{DAFTAR PUSTAKA}

B. H. (2019, April 24). Daerah Pemasaran. (Meriam, Interviewer)

Budiman, A. (2016). Hikayat Kretek. Jakarta: PT.Gramedia.

Daliman, A. (2012). Metode Penelitian Sejarah. Yogyakarta: Ombak.

Darmiati. (2019, April 25). Dampak Ekonomi. (Meriam, Interviewer)

Hamid, a. r., \& Majdid, M. S. (2011). Pengantar Ilmu Sejarah.

Yogyakarta: Ombak.

Hernowo, B. (2009, April 24). Dampak Sosial. (Meriam, Interviewer)

Hernowo, B. (2018, September 20). Data Karyawan. (Meriam, Interviewer)

Hernowo, B. (2018, September 20). latar Belakang. (Meriam, Interviewer)

Hernowo, B. (2019, April 23). latar Belakang Belakang Berdirinya Industri. (Meriam, Interviewer)

Jumiati. (2019, April 24). Dampak Sosial. (Meriam, Interviewer)

Kartasapoetra, G. (1992). Marketing Produk Pertanian dan Industri. Jakarta: Rineka Cipta.

Maadjid, A. R. (2004). Pengantar Ilmu Sosial. Yogyakarta: Ombak.

Markus, S. (2015). Petani Tembakau di Indonesia Sebagai Paradox

Kehidupan . Yogyakarta:

Leutikaprio.

Parerung, L. (2019, April 23). Dampak Sosial. (Meriam, Interviewer)

Partomo, T. S. (2002). Ekonomi Skala Kecil/Menengah dan Koperasi. Jakarta: Ghalia Indonesia.

Pranoto, S. W. (2010). Teori dan Metodologi Sejarah. Yogyakarta: Graha Ilmu. 
Rahman, A. A. (2011). Hitam Putih Tembakau . Depok: FISIP IU PRESS.

Statistik, B. P. (2018). Kabupaten Soppeng dalam Angka 2018. Soppeng: Badan Pusat Statistik Kabupaten Soppeng.

Tahir, A. (1992). Ekonomi Selayang Pandang. Bandung: Sumur Bandung.

Topatimasang, R. (2010). Kretek Kajian Ekonomi dan Budaya 4 Kota. Jakarta: PT.Buku Kita .

Widja, I. G. (1989). Sejarah Lokal Suatu Perspektif Dalam Pengajaran Sejarah. Jakarta: Depdikbud.

Wie, T. K. (1997). Pengembangan Kemampuan Teknologi Industri Indonesia. Jakarata: Universitas Indonesia. 